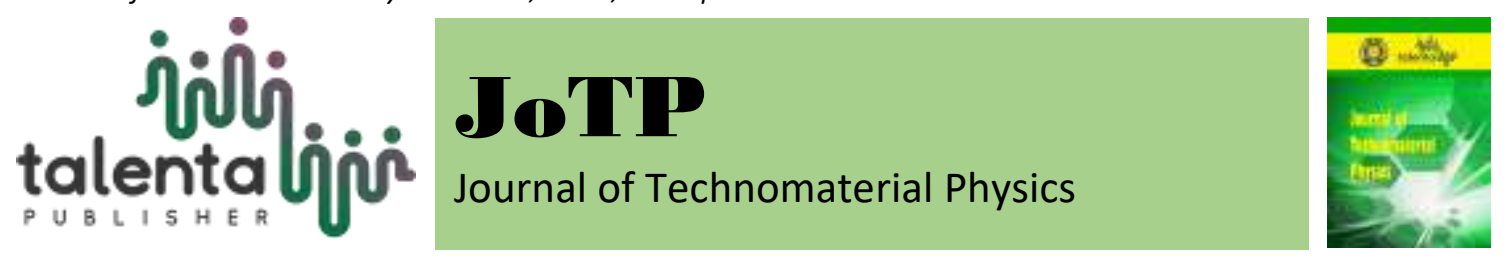

\title{
The Utilization of Areca Skin Fiber - Pumice and Epoxy Resin Towards The Characterization of Concrete Polymer
}

\author{
Lukman Hakim ${ }^{1}$, Fauzi ${ }^{2}$ and Limbong ${ }^{3}$ \\ ${ }^{1,2,3}$ Department of Physics, Faculty of Mathematics and Natural Science, Universitas Sumatera Utara, \\ Medan 20155, Indonesia
}

\begin{abstract}
The manufacturing and characterization of polymer concrete made from the mixture of areca fiber, pumice and sand as an aggregate and epoxy resin as a binder material has been conducted. The mixture of sand, pumice and areca shell fiber varies with $(50: 50: 0) \mathrm{g},(49: 49: 2) \mathrm{g},(48: 48: 4) \mathrm{g},(47: 47: 6) \mathrm{g},(46: 46: 8) \mathrm{g},(45: 45: 10) \mathrm{g}$ respectively, and epoxy resin (25.30) $g$ in every variation of aggregate (sand + pumice + areca fiber). The results reveal that the best mixture composition in accordance to the experiment was a mixture of sand and areca shell with a ratio of 48:48:2 $\mathrm{g}$ as well as the addition of $30 \mathrm{~g}$ epoxy resin. The physical properties of polymer concrete were analyzed. The density was $1.81\left(\mathrm{~g} . \mathrm{cm}^{-3}\right)$ and porosity was $1 \%$. Moreover, the mechanical properties were also analyzed by performing the impact test with the result of $7.5 \mathrm{KJ} / \mathrm{m}^{2}$ and bending strength test was 16.94 MPa. The XRD analysis indicated the presence of quartz, pumice stone, quartz, pumice stone hexagonal, while the areca fiber has an amorphous crystal shape.
\end{abstract}

Keywords: Areca Skin Fiber, Pumice, Sand, Epoxy Resins, Polymer Concrete.

Received 12 December 2018 | Revised [15 February 2019] | Accepted [28 February 2019]

\section{Introduction}

The development of material technology for various community needs such as household appliances, sports equipment and others is rapidly increasing and much needed. One type of need is concrete material. To meet the concrete needs, efforts are made to make concrete types become more efficient. The method conducted is to manufacture concrete from polymer. Polymer material is an alternative to produce material which possesses better mechanical properties in certain aspects of other materials.

Concrete is a stone material obtained by making a mixture that resembles a certain proportion of cement, sand or other aggregates, and water to make the mixture hard in a mold based to the desired shape and structural dimensions [1-5].

*Corresponding author at: Jl. Bioteknologi No.1 Kampus USU, Medan, Indonesia, 20155

E-mail address: lukmanhakim@usu.ac.id 
Polymer is one type of material that is made by combining two or more kinds of materials that have different properties into one new material with different properties. Polymers have advantages such as strong, lightweight, corrosion resistant, and affordable. In making this polymer concrete, fiber and aggregate composites are needed. Fiber functions as a reinforcing element that determines the mechanical properties of the polymer. Based on its existence, fiber is divided into two, namely natural fiber and synthetic fiber. In this case, the composite fiber used is natural fiber. Aggregate is one material that is used as a constituent of concrete. Generally, aggregates are divided into two, which is coarse aggregate (gravel / stone) and fine aggregate (sand). The function of coarse aggregates is as the main component that contributes most power to prospective concrete later. In general, the strength of concrete depends on the aggregate strength in the concrete composition.

Natural fiber used in this study is Areca Catechu L. It is a type of plant that has light fiber. This plant is found in the area of Central Tapanuli with the local name of Pinang. The use of betel bark (Areca catechu L.) as an ingredient in making concrete has not been known by the public so that this fiber is a new innovation for manufacturing polymers. Pinang skin fiber (Areca catechu L.) is cleaned first before being mixed with other ingredients. Areca bark composite materials are used to reduce mass in all polymer reinforcing materials.

The quality of coarse and fine aggregates also affects its strength. While the function of fine aggregate on concrete is as filler materials that will reduce and even cover the air cavities or empty cavities between coarse aggregates. The denser the concrete structure, the higher the compressive strength produced. Therefore, a fine aggregate is extremely needed in the concrete manufacture.

The aggregate material used in this study was pumice and sand. The reason for choosing this aggregate of pung stone is the pumice mass factor which is relatively light compared to other rock types. The existence of quartz sand is as an ingredient to increase the hardness.

As an adhesive material for the manufacture of concrete, epoxy resin is used. This material was chosen for its better mechanical properties compared to more common polyester resins. Epoxy is used for the manufacture of high strength and relatively lowers mass polymer materials.

\section{Materials and Methods}

Before the sand was synthesized, pumice stone was washed thoroughly, dried and then it is smoothed. Sand and pumice stone were sieved with 100 mesh sieve and areca nut husk was cutted off and then soaked with distilled water for 2 hours then dried. Those three materials were each weighed and then mixed by adding epoxy and tinner resin adhesives to reduce the viscosity and stirred in a container so that the mixture is then poured into a mold made of steel. The mold model is in the form of a beam $(10 \times 2 \times 1) \mathrm{cm}$, the drying or hardening process was 
performed on a hot compressor as high as $90^{\circ} \mathrm{C}$ for 30 minutes using the Universal Testing Machine Sc-2DE, so that a polymer concrete sample was formed then soaked in water for 24 hours. Furthermore, the density testing was conducted refers to ASTM C.134-95 standard, porosity refers to ASTM C. 237-88 standard, flexural strength refers to ASTM C standard 34897, impact strength refers to ASTM D 256 standard and XRD analysis respectively. The equipment used in the study of flexural strength was using the Standard Test Method for Flectural Strength of Hydroulic Cement Mortar, ASTM USA.2002, impact strength using the Wolpert Impaction tool. X-ray diffraction (XRD, RINT-Rigaku).

\subsection{The Research Procedure Flow Chart}

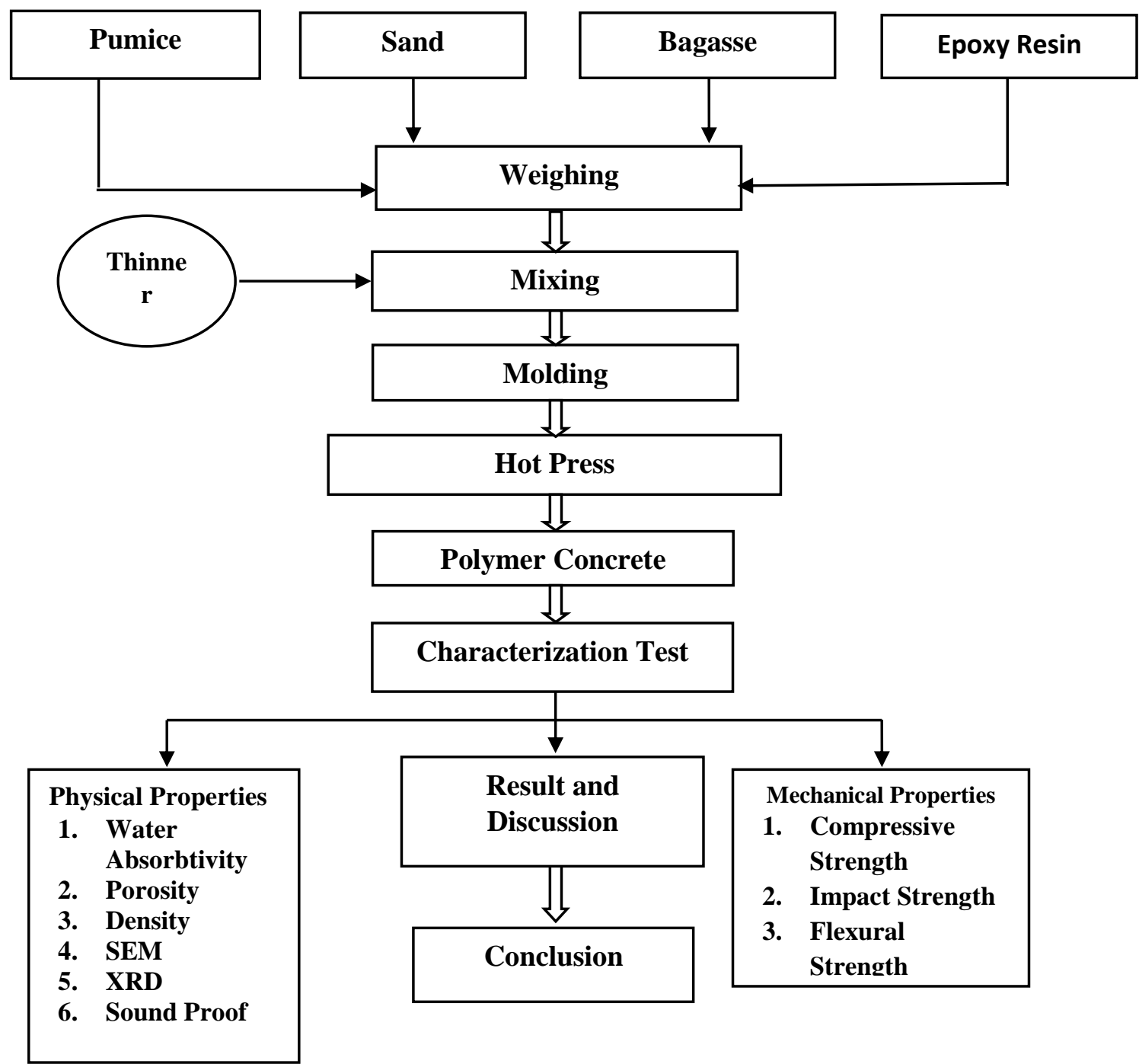

Figure 1. The procedure of research in characterizing polymer concrete of pumice and bargasse

\section{Result and Discussion}

\subsection{Density Test}

The density analysis of polymer concrete was based to the standard of ASTM.C 134-95 with the equation : 


$$
\rho=\frac{m_{k}}{m_{k}-\left(m_{s g}-m_{k p}\right)} \rho_{\text {water }}
$$

where $\rho_{\text {water }}$ is density of concrete $\left(\mathrm{g} / \mathrm{cm}^{3}\right), \mathrm{V}$ is volume of concrete $\left(\mathrm{cm}^{3}\right), \mathrm{m}_{\mathrm{kp}}$ is the weight of hanging wire samples (gram), $\mathrm{m}_{\mathrm{sg}}$ is the weight of sample in water (gram) and $\mathrm{m}_{\mathrm{k}}$ is the weight of dried sample (gram).

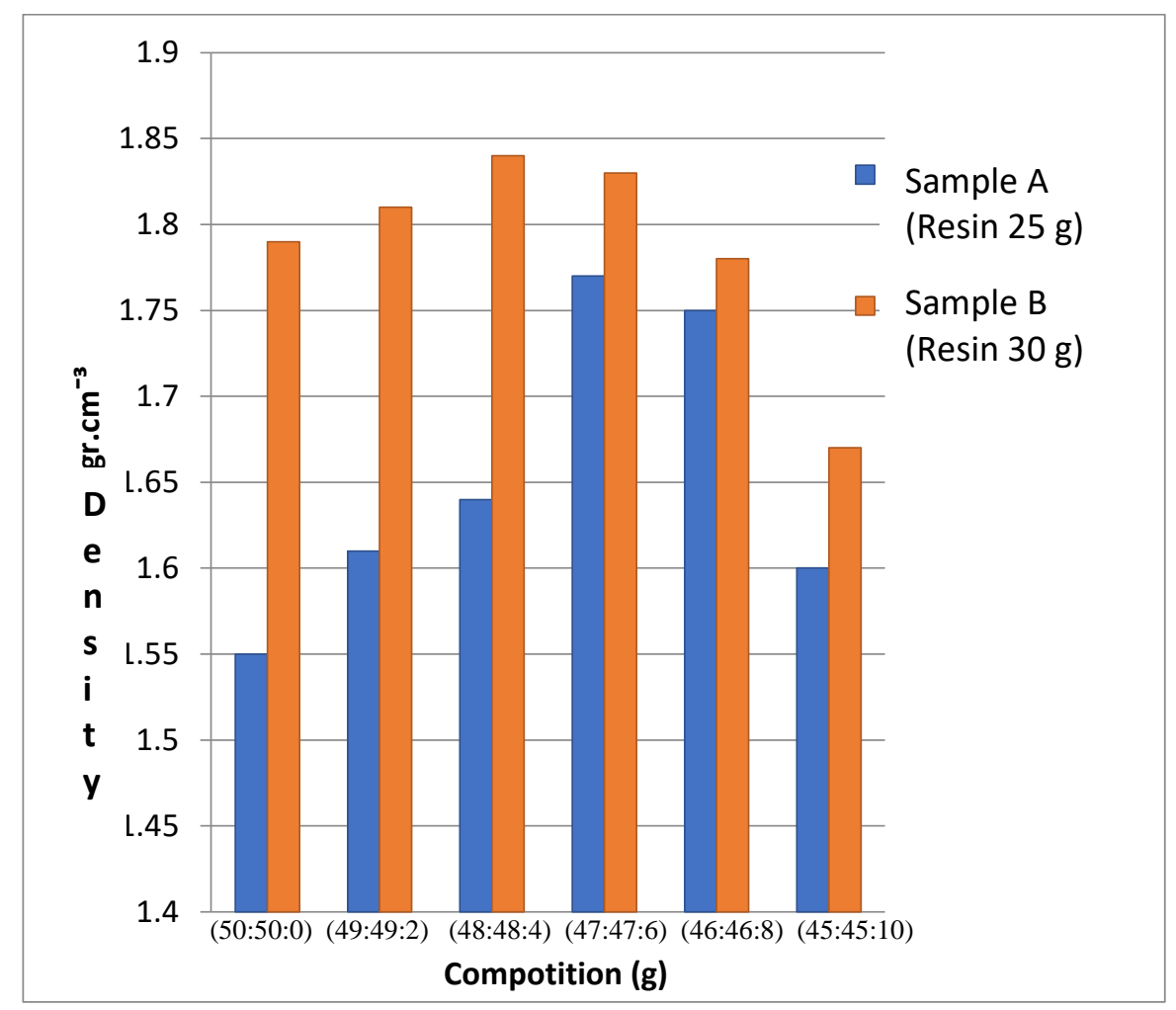

Figure 2. The relationship between density test result and the sample composition

From figure 2, it can be seen that the density of polymer concrete ranges from 1.55 to 1.84 $\mathrm{g} / \mathrm{cm}^{3}$. With the addition of $4 \mathrm{~g}$ areca nut fiber to the composition (48: 48: 4) as a maximum density value. This shows that areca nut fiber as filler greatly affects the grain between atoms where the pores between atoms are enlarged. This is because pumice tends to absorb more epoxy resin when compared to areca nut fiber in general for conventional concrete (Portland cement) the density value is $2.307 \mathrm{~g} / \mathrm{cm}^{3}$ and for cement pumice is $1.81 \mathrm{~g} / \mathrm{cm}^{3}$. Meanwhile, according to reference [1] light brick with a density $(1.4-1.8) \mathrm{g} / \mathrm{cm}^{3}$ can be used as a bearing wall.

\subsection{Porosity Test}

The porosity analysis of polymer concrete was based to the standard of ASTM C.237-88 with the equation:

$$
\mathrm{P}=\frac{M_{b}-M_{k}}{V_{b}} \times \rho_{\text {water }} \times 100 \%
$$

where $\mathrm{P}$ is porosity (\%), $\mathrm{M}_{\mathrm{b}}$ is the weight of wet sample $(\mathrm{g}), \mathrm{M}_{\mathrm{k}}$ is the weight of dried sample $(\mathrm{gr}), \mathrm{V}_{\mathrm{b}}$ is the volume of sample $\left(\mathrm{cm}^{3}\right)$ and $\rho_{\text {water }}$ is water density $\left(\mathrm{g} / \mathrm{cm}^{3}\right)$. 


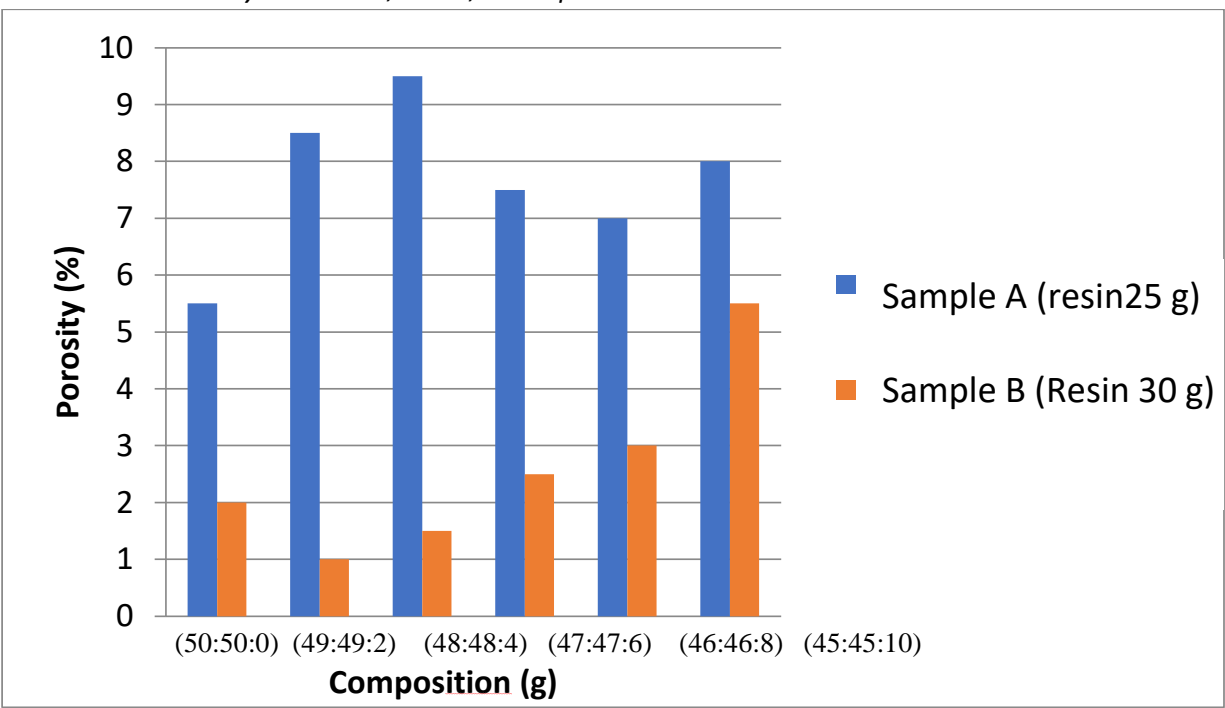

Figure 3. The relationship between porosity and sample composition

The relationship between porosity and polymer concrete composition is shown in Figure 3. The results of polymer concrete porosity measurements obtained was ranged from $1 \%-9.5 \%$. The more amount of areca skin included, the greater the porosity value. This is due to the nature of areca nut waste which can cover the pores and become stronger atoms. With the addition of epoxy resin, the porosity value is reduced since epoxy resin will fill the pores and cover micro defects in polymer concrete so that the porosity is smaller. While other researchers have made polymer concrete with pumice and epoxy resin aggregates with oven dry treatment, its porosity was recorded to be $7.8 \%$

\subsection{Impact Strength Test}

The impact strength of polymer concrete was based to the standard of ASTM D 638. With the equation:

$$
\text { Impact Strength }(\sigma)=\frac{E_{\text {absorbtion }}}{A}
$$

where $\sigma$ is impact strength $\left(\mathrm{J} / \mathrm{m}^{2}\right), \mathrm{E}_{\text {absorbtion }}$ is energy absorbed $(\mathrm{J})$ and A is area of sample $\left(\mathrm{m}^{2}\right)$.

Based on the result, impact strength of polymer concrete was obtained with range of (1.62 - 8.2) $\mathrm{KJ} / \mathrm{m}^{2}$. From Figure 4, it can be seen that the addition of areca nut fiber waste greatly affects the ability of objects to receive pressure. In other words, the more areca nut fiber used, the stronger the impact. Likewise, the addition of epoxy receipts and areca nut fiber waste greatly affects the impact strength, because the nature of epoxy resin has a good binding ability so it has good toughness. This has been proven by several research data on natural bending as done by Gonzales [6-9]. 


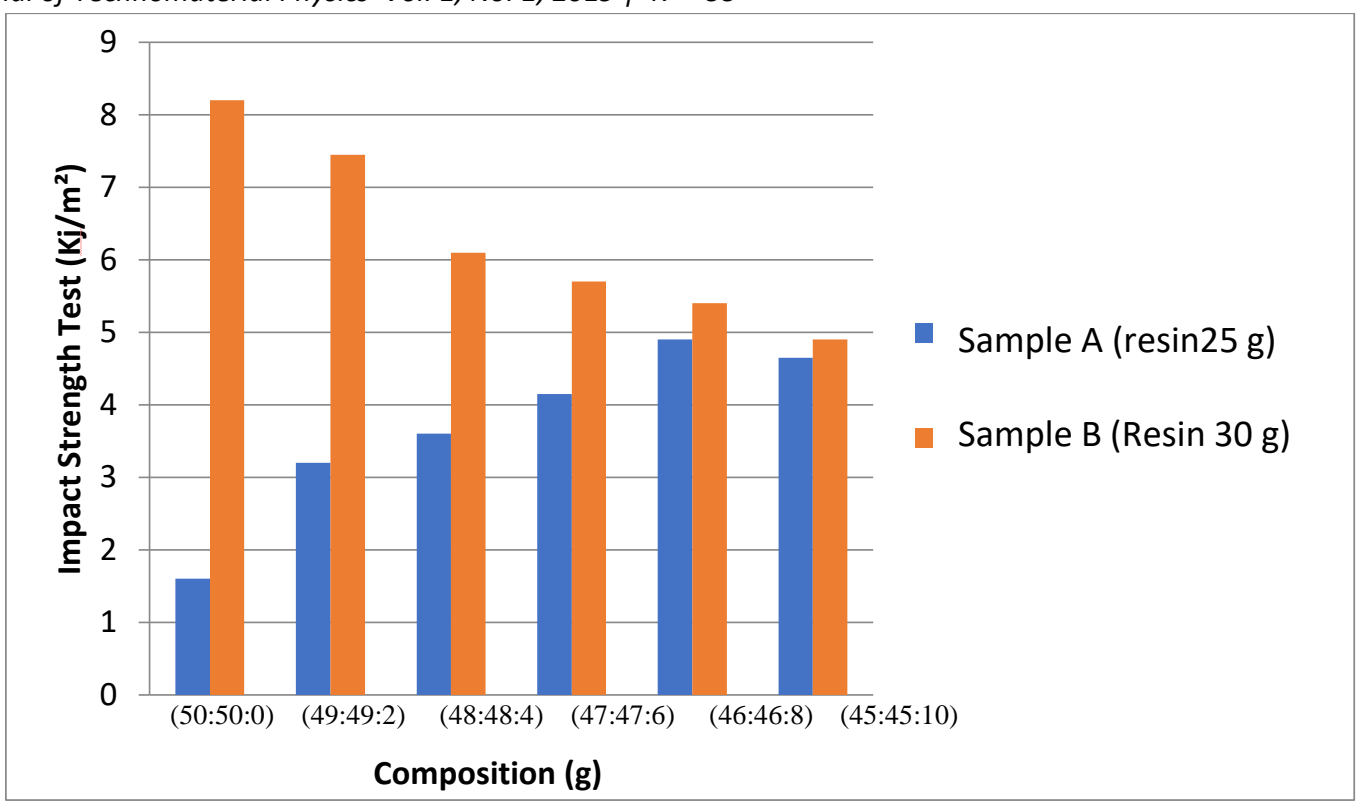

Figure 4. The relationship between impact strength test and sample composition

\subsection{Flexural Strength Test}

The flexural strength of polymer concrete was based to the standard of ASTM.C. $343-97$. Using the equation of:

$$
F_{l t}=\frac{3 P L}{2 b d^{2}}
$$

where $F_{l t}$ is flexural strength $\left(\mathrm{Nm}^{-2}\right), b$ is wide of sample $(\mathrm{m}), \mathrm{P}$ is pressure $(\mathrm{N}), \mathrm{d}$ is thickness of sample $(\mathrm{m})$ and $\mathrm{L}$ is distance $(\mathrm{m})$.

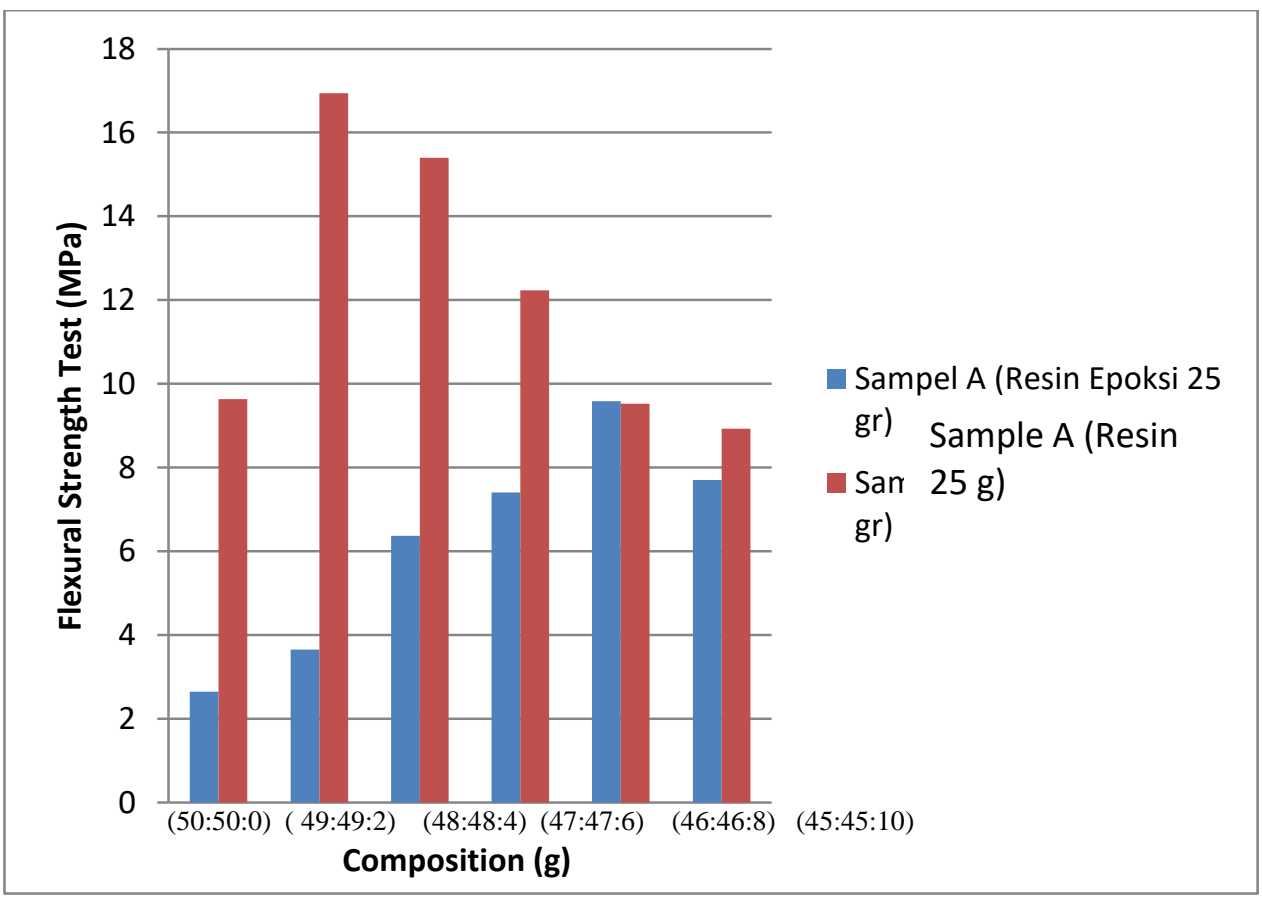

Figure 5. The relationship between flexural strength test and sample composition

Based on figure 5, it can be seen that the more sand and pumice was added, the flexural strength increased. In the other hand, if the areca nut fiber was added, the flexural strength decreased, so 
did the addition of epoxy resin caused the higher flexural strength. Figure 5 indicated the maximum flexural strength is $16.94 \mathrm{MPa}$ with the composition (49: 49: 2) and 30\% epoxy resin of total weight, while the minimum flexural strength is $2.62 \mathrm{MPa}$ in composition (50: 50: 0) with $25 \%$ epoxy resin. This shows that the reduction of agrarian elements bond or can also occur due to reduced adhesive ability so that the inter-particle bond is low.

This results the absence of homogeneity in the polymer mixture, the epoxy resin increases and the flexural strength becomes stronger, since epoxy resin easily flows to fill the existing cavities or cover the defective parts so as to increase the flexural strength. As a comparison, conventional concrete flexural strength is around 2.5 MPa [10-13]. The flexural strength of the polymer concrete and the partial value is still below the concrete of the polymer made. For semi-polymer concrete, the flexural strength value is $14 \mathrm{GPa}$ [14]. This value is relatively much smaller compared to the polymer concrete obtained.

\subsection{SEM analysis of polymer concrete}

Figure 6 shows a SEM result of concrete with the composition of 48 gram sand, 48 gram pumice and 2 gram of areca nut fiber with the addition of 30 gram epoxy resin.

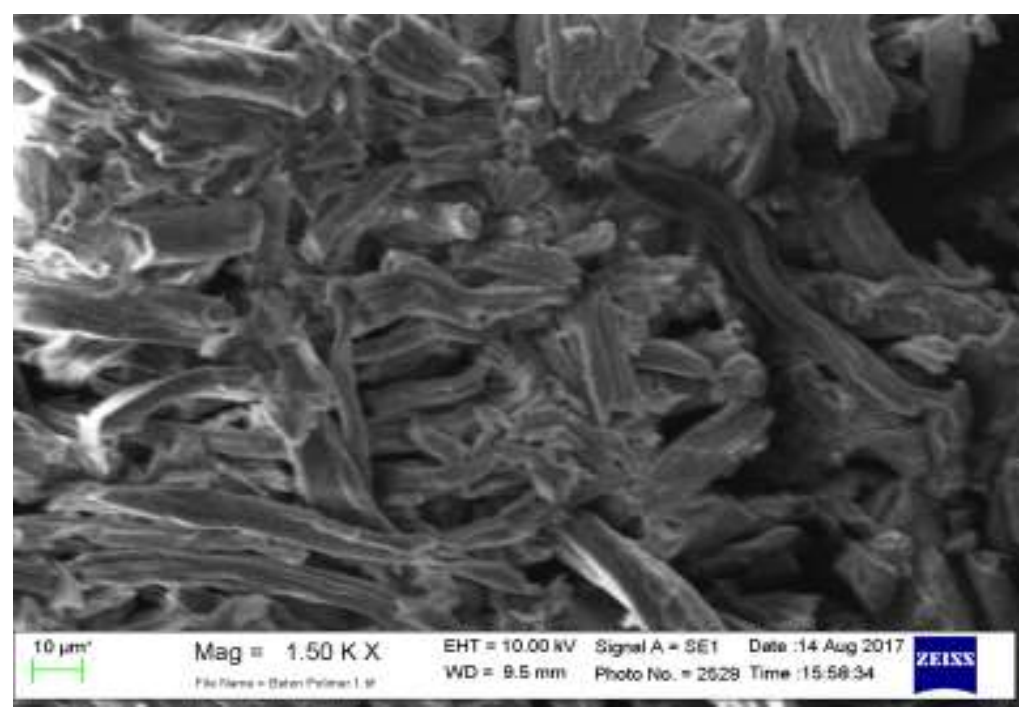

Figure 6. SEM of polymer concrete

It can be seen that there are a small portion of cavities which are marked in black or dark, while gray corresponds to a lump of areca fiber mixed with sand, and pumice is mixed in concrete. White or bright color is a lump of epoxy resin. The cavities in the concrete are distributed unevenly with a size of around 5-40 $\mu \mathrm{m}$, the size of the epoxy resin lump is about $10 \mu \mathrm{m}$. While the shape of sand particles and pumice is not visible in the grain boundary. According to Ungkoon [15-18] naturally dried concrete has a rougher surface and larger pore size, less amount and uneven distribution. The existence of micro-defects (micro cracks) in the concrete causes the mechanical strength to fall, because it facilitates the occurrence of cracks or fractures. In concrete with a smoother surface, small particle size, generally without defects and relatively denser, it tends to have a higher mechanical strength. 


\subsection{X-Ray Diffraction Analysis}

The analysis of polymer concrete with mixed composition (sand, pumice, areca nut fiber) was identified using X-ray diffraction. The concrete has a mixture composition of (49:49:2) with $30 \%$ epoxy resin and shown in Figure 7.

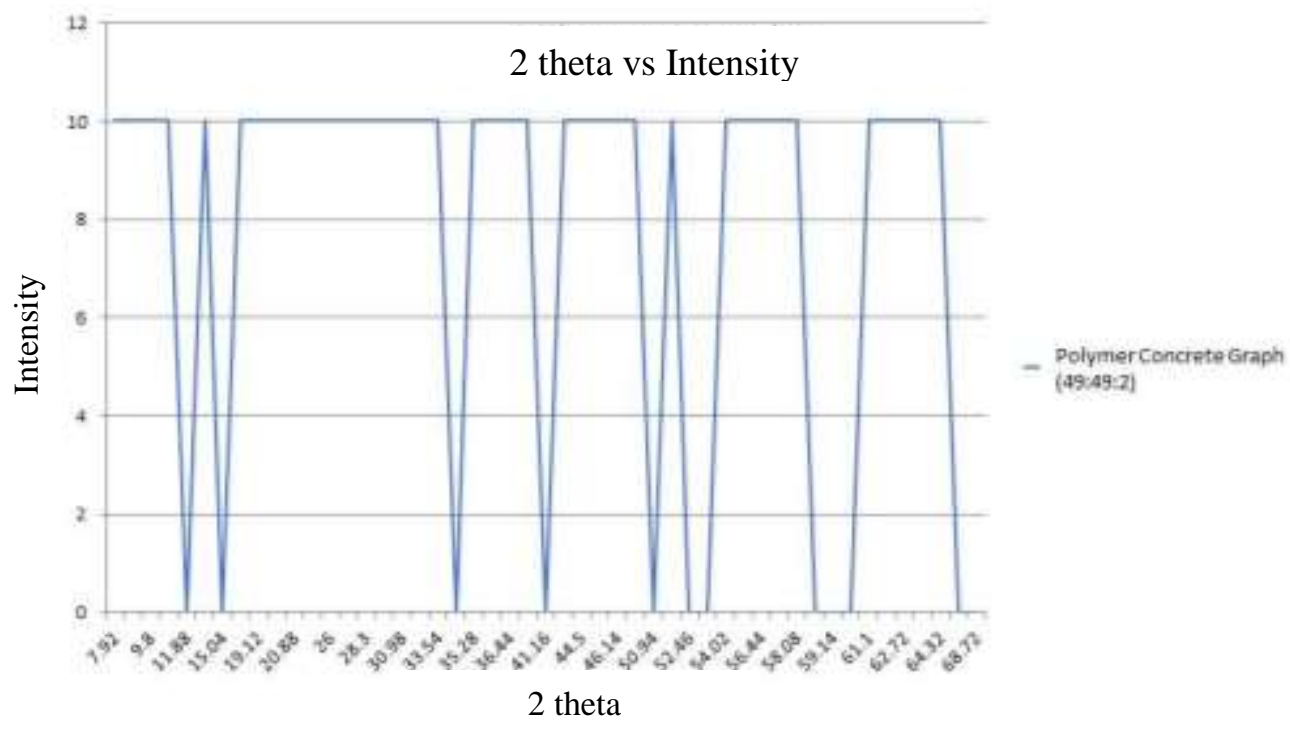

Figure 7. The graph of X-ray diffraction analysis result

X-ray diffraction indicates that several peak heights were identified. The XRD form of the polymer concrete with $30 \%$ epoxy resin shows that the sand peak (quartz) is evenly distributed with atomic distances from $11.15 \mathrm{~A} 0$ to $1.36 \mathrm{~A} 0$. The other peak shows pumice with atomic distance (d) $7.44 \mathrm{~A} 0,5.88 \mathrm{~A} 0,2.59 \mathrm{~A} 0,2.19 \mathrm{~A} 0,1.79 \mathrm{~A} 0,1.74 \mathrm{~A} 0,1.70 \mathrm{~A} 0,1.57 \mathrm{~A} 0,1.56 \mathrm{~A} 0$, $1.54 \mathrm{~A} 0$, and $1.36 \mathrm{~A} 0$. From the XRD analysis result, it can be concluded that polymer concrete is a mixture of various materials in the form of hexagonal sand and crystal. However, areca nut fiber is amorphous which contributes to the polymer concrete mixture $[19,20]$.

\section{Conclusion}

Based on the research that has been conducted regarding the manufacture and characterization of polymer concrete by utilizing pumice, areca nut fiber and sand and epoxy resin as adhesive, conclusions can be drawn as:

1. The best mixing composition was produced in polymer concrete with a sample code B2 that is with a mixture of $2 \mathrm{~g}$ of areca nut fiber, $48 \mathrm{~g}$ of sand, $48 \mathrm{~g}$ of pumice stone with $30 \mathrm{~g}$ of epoxy resin and $15 \mathrm{~g}$ of thinner. The optimum polymer concrete produced has the following characteristics: density $=1.81\left(\mathrm{~g} / \mathrm{cm}^{3}\right)$, porosity $=1 \%$, impact strength $=7.45$ $\mathrm{KJ} / \mathrm{m}^{2}$ and flexural strength $=16.94 \mathrm{MPa}$.

2. In the previous concrete research using Portland, Sand, Gravel and Ijuk Fiber materials, the lowest density value was found to be $2.1 \mathrm{~g} / \mathrm{cm}^{3}$. While the lowest density value in this study was $1.55 \mathrm{~g} / \mathrm{cm}^{3}$. Therefore, in order to get concrete with a low density value, the results of this study are better compared to the previous one. 
3. The SEM-EDX microstructure is also influenced by the composition of a mixture of pumice, sand (1: 1), areca nut fiber and epoxy resin. The sample surface and porosity of the sample will be well distributed if the epoxy resin binds well so that there is not much cavity in the polymer concrete.

\section{REFERENCES}

[1] A. Balaga and J. J. Beandoin, Polymer Modified Concrete, Canada: Canadian Building Digest, 1985.

[2] Ohama, Yoshihiko. Handbook of polymer-modified concrete and mortars: properties and process technology. William Andrew, 1995.

[3] Huang, Baoshan, et al. "Laboratory evaluation of permeability and strength of polymermodified pervious concrete." Construction and Building Materials 24.5 (2010): 818-823.

[4] Pascal, Serge, A. Alliche, and Ph Pilvin. "Mechanical behaviour of polymer modified mortars." Materials Science and Engineering: A 380.1-2 (2004): 1-8.

[5] Bentur, Arnon, Neal Berke, and Sidney Diamond. Steel corrosion in concrete: fundamentals and civil engineering practice. CRC Press, 1997.

[6] V. Gonzales, "A Study into the Processing of Bitumen Modified with Tire Crumb and Polymer," Journal Fuel Processing Technology, vol. 95, pp. 137-143, 2012.

[7] Sienkiewicz, Maciej, et al. "Environmentally friendly polymer-rubber composites obtained from waste tyres: A review." Journal of cleaner production 147 (2017): 560-571.

[8] Zhang, Feng, and Changbin Hu. "The research for structural characteristics and modification mechanism of crumb rubber compound modified asphalts." Construction and Building Materials 76 (2015): 330-342.

[9] Sienkiewicz, Maciej, et al. "Development of methods improving storage stability of bitumen modified with ground tire rubber: A review." Fuel Processing Technology 159 (2017): 272-279.

[10] S. Iman, Light Weight Styrafoam Concrete for Highter and more Ductile Wall, Yogyakarta: Universitas Gadjah Mada, 2005.

[11] Parung, Herman, Muhammad W. Tjaronge, and Rudy Djamaluddin. "Flexural characteristics of reinforced concrete beam using styrofoam filled concrete (SFC) in tension zone." International Journal of Engineering and Technology 7.1 (2015): 1.

[12] Irmawaty, R., R. Djamaluddin, and Wa OAR Malim. "Flexural Behavior Of StyrofoamFilled Concrete." International Journal of Engineering and Science Applications 3.1 (2016): 9-14.

[13] Prayitno, Slamet, Sunarmasto Sunarmasto, and Aris Munandar. "Pengaruh Penambahan Serat Bendrat Dan Styrofoam Pada Beton Ringan Terhadap Kuat Tekan, Modulus Of Rupture, Dan Ketahanan Kejut (Impact)." Matriks Teknik Sipil 5.3 (2017).

[14] P. Sebayang, T. Anggito, D. S. K and Mulyadi, "Pengaruh Proses Angin Terhadap Karakterisasi Beton Geopolymer," Teknik Kimia Surabaya, Surabaya, 2008.

[15] U. Yathin, Analysis Autaclaved aerated wall construction material, Thailand, 2008.

[16] Jumiati, Ety. Pembuatan beton semen polimer berbasis sampah rumah tangga dan karakterisasinya. MS thesis. 2009.

[17] Meilanda, Heni. "Pemanfaatan Serat Cangkang Kulit Kopi dalam Pembuatan Beton Polimer dengan Resin Polyester sebagai Perekat." (2018).

[18] Amirudin, Nursyafril. "Pedoman Konstruksi Beton." (1982).

[19] D. V. C. Siregar, "Karakterisasi Beton Polimer dari Agregat Pasir dan Batu Apung serta Limbah Serat Ampas Tebu sebagai Filler dengan Resin Epoksi sebagai Perekat," FMIPA USU, Medan, 2017.

[20] Lubis, Muslimin. Pemanfaatan Ampas Tebu Dalam Pembuatan Batakoringan Yang Direncanakan Sebagai Konstruksidinding Kedap Suara. MS thesis. 2010. 